\title{
A Semiotic Analysis of Gender Discursive Patterns in Pakistani Television Commercials
}

\author{
Muhammad Haseeb Nasir ${ }^{1}$ \\ ${ }^{1}$ Faculty of English Studies, National University of Modern Languages, Islamabad, Pakistan \\ Correspondence: Muhammad Haseeb Nasir, Faculty of English Studies, National University of Modern \\ Languages, Islamabad, Pakistan. E-mail: nasirhaseeb87@gmail.com
}

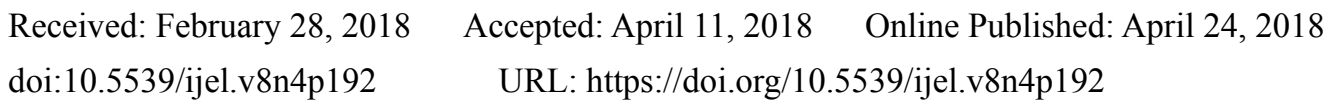

\begin{abstract}
The study is multidisciplinary that ventures into the domains of semiotics, linguistics and cultural studies. Media has become one of the most viable social institutions of disseminating information to a wider audience. It has got power to (re)frame the ideology of larger audience through its visual/linguistic content and to pave the way to social change. The current study aims to investigate the manifestation of gender discursive patterns in the Pakistani television commercials. This study draws its theoretical foundation on the theory of semiotics propounded by Dyer (1982) in her book Advertising as Communication. Semiotics is conceived an appropriate tool for the critical inquiry of the televised commercials because of its wide ranging acceptability and reliability in the meaning making process. Williamson (1978), Dyer (1982) and Jhally (1990) not only recommended but they also practically employed semiotics as a tool of investigation for critically examining the meaning making process in the commercials that enhances the reliability and validity of semiotics as a tool of inquiry. The data for the current study comprises television commercials broadcasted on famous Pakistani television channels. The sampling technique is based on non-probability purposive sampling. The rationale of choosing purposive sampling technique is to include only those commercials which reflect gender representation. The findings of the study highlight that the commercials present layers of meanings via semiotic modes at symbolic level where men and women are displayed in stereotypical manner. The existing gender narratives in the Pakistani commercials subscribes to patriarchal structures. The study presents recommendations about the change in the content of the televised material and also highlights the unexplored avenues which can be brought under considerations by the future researchers.
\end{abstract}

Keywords: semiotics, representation, television commercials, gender

\section{Introduction}

Media plays a significant role in portraying culturally dominated binary narrative where the television commercials being one of the popular media frame the attitude of people. According to Cook (2005), media advertisements as one of the significant social institutions are prominent in all contemporary societies. While talking about the services and products provided in the advertisements, the commercials develop a secondary discourse about socially framed gender power relations. The image of male/female in the commercials is linked to the understanding of their social interaction, power and social practices. That is why, the advertisements posit ideology through signs that reflect existing cultural norms in a society. The construction of masculinity and femininity is promoted through social practices incorporated in the commercials.

Commercials are taken as representatives of cultural text which include human subjects to promote the advertised products/objects. These commercials incorporate gender as cultural texts which signify prevalent dominant power structures at symbolic level. The ideology propagated in the commercials serves to maintain the hegemony of a socially constituted gender order. Roy (1998) argues that the commercials not only provide information about the appearance, manner and activity of human subjects but they also serve to explain culturally defined gender roles at symbolic level. Commercials embody cultural norms that are perceived as a key agent in reinforcing social constructs through visuals.

Gender is perceived as an axis of social order where the narrative of masculinity and femininity is purely a social construct. These constructs are materialized through various social institutions like print/electronic/social media, academia and sports. Similarly, Sutherland, Gilbert, \& Taylor (1992) claim that advertising has gradually become 
a very significant institution where it represents the masculine and feminine voices at symbolic level in the commercials The current study interprets the said gender notions that are promoted through television commercials which we come across in everyday life. The television commercials not only endorse socially constructed gender beliefs but they also make us accept whatever content is presented in the form of running visuals.

The research objectives of the present study are given below

$>$ To highlight the manifestation of existing gender-binary relations in Pakistani television commercials;

$>$ To explore the semiotic interpretation of the role/activity assigned to men/women in Pakistani television commercials.

\section{Literature Review}

The manifestation of gender varies from country to country and its representational mechanism is context dependent, making gender research a purely social construct. Though past studies conducted in the paradigm of gender have delineated correlational value of gender and advertising explicitly, yet there are certain areas which still remained unexplored. According to Furnham \& Bitar (1993), the focus of previous studies remained on developed English speaking countries but there has been deficiency of a critical gender research in third world developing countries like Pakistan. With an aim to address this gap, the current study examines the gender structures in Pakistani television commercials and analyzes what underlying ideological assumptions these commercials promote.

\subsection{Emergence of Advertising in Pakistan}

The evolution of Advertising in Pakistan refers back to 1947, with the partition of Sub-continent into Pakistan and India. It has undergone through several phases from 1947 to date. In first era (1947-1964), due to limited resources and lack of awareness, advertising was restricted to some regional and urban areas where print media advertisements were popular medium. Newspapers were considered as the only medium for the commercial communicative purposes.

According to International Media Support (2009) report, the historical background and development of media in Pakistan refers to pre-partition era when media was introduced to propagate Muslim's voice for a separate ideological state. The establishment of "Dawn" by Quaid-i-Azam in 1941, was introduced to counter the narrative of Non-Muslims. Nawa-i- waqt also worked on the same stance and was introduced in 1940.

McNair (2003) defines advertising as a paid medium through which organizations convey their messages and promote their products. Human representation is an essential part of these advertisements because through their voice, messages have been transmitted effectively. The treatment of human subjects in media differs because of socially fabricated constructs. Studies on content of the television commercials generated a secondary discourse as to what and who are involved in the production of the advertisements.

\subsection{Gender Representation in Media}

Media is thought to be one of the reliable social institutions which highlight the positional value of men and women within a socio-cultural paradigm. Lemish (2005) conducted her study on Israeli media and unveiled the projection of women in restricted spheres of life. She also compared her findings with the previous researches conducted on the said subject. She concluded that women are mostly shown attached to a particular domain of life (domesticity). They are depicted as sexual and reproductive object. According to her, women are the victimized creature, who are presented as an object to please their counterparts.

Rasul (2000) is of the view that women models are shown as an item/object for the sake of product promotion. Such advertisements are part of today's televised content. These biased gender representations are not only restricted to print media advertisements or televised content but gender is almost found in all spheres of human activity. The following section highlights the representation of men and women in electronic media advertisements. It would also focus on the methodological approaches incorporated by scholars to conduct their studies and to investigate the gender relations in electronic media discourse.

\subsection{Gender Representation in Print Media}

The importance of print media can never be overlooked being a cheap and easily available source of information, entertainment and education. It has remained one of the most powerful sources which framed the concepts and perceptions of people. Print media images and text not only strengthen the beliefs but also represent socio-cultural values, favoring dominating structures. Hall (1997) argues that print media text shares cultural meaning through visual or linguistic signs. Representation of cultural meanings shared with society can only be 
propagated either via images or linguistic representation. These images cultivate culturally constructed meanings at symbolic level.

Representation of gender in print media can be viewed from multi-perspectives such as analyzing the ratio of men and women in the workplace advertisements, in sports section, in news section and magazines. Traditionally, gender depiction refers to presentation of men/women where men are given their due rights and powers while women are deprived of their rights. They are shown subjugated/suppressed by the male dominant voices and are positioned low in gender relations. Media Development and Diversity Agency MMDA (2008) declares media as one of the important pillars of democracy. It further reports that inequalities and biased cultural distribution of power has been naturalized by media through its different genres like print, electronic and social media.

\subsection{Gender Representation in Television Commercials}

Since 1970's, gender research with reference to the portrayal of men/women in television content has been a debated topic for scholars round the globe. Courtney \& Whipple (1983) suggest that the issue of gender roles and stereotyping in TV commercials became more prominent with the arrival of feminist discourse. Much of the content analysis has been produced on television advertising with regard to gender representation. Bretl \& Cantor (1988) reported that almost eleven studies had been conducted on the televised content of gender portrayal in US Television commercials.

Craig (1992) is of the view that advertisers intentionally incorporate gender biased structures in the commercials in order to either strengthen the existing traditional viewpoint. Craig (1992) opines that societal structures like patriarchy do not allow advertisers and agencies to portray men and women in the same manner. The advertisers present men and women in different roles. Therefore, the stereotyped images of men and women in the televised commercials reveal their identity.

Gender representation in Pakistan has also been a purely research oriented topic of discussion. The ratio of gender disparities in third world and developing Asian countries have been highlighted in previous discussion. A sound discussion has been generated in recent sections of literature review with regard to gender representation in Asian countries such as Philippines, India and Bangladesh, indicating the discriminatory attitude of advertisers while portraying men and women in print, electronic and social media.

According to Pakistan Economic Survey report (2001-2012), Pakistan appears to be the most striking and promising country in the promotion of consumer market in the world. Pakistan is a matchless state, having cultural and linguistic diversity, and stands as the sixth largest country in the world. The total population of Pakistan is almost over 180 million which has been growing by the rate of $2.03 \%$ per year. According to The World Fact-book (2011), the estimated population of the female ratio is almost equal to male population in Pakistan. Recent studies in gender representation had shown unequal representation and traditional roles assigned to women. Women are making their way to equal representation in work situations and contributing to the progress and development of the country. Enhancing their active participation in different domains of life can bring forth the equality of gender at national level.

\section{Research Methodology}

The current study falls into the qualitative paradigm of research. It follows descriptive and explanatory qualitative procedure to analyze and interpret the data on the basis of the features drawn from the theory of semiotics, proposed by Gillian Dyer (1982). Polkinghorne (1983) suggests that qualitative research as a method encompasses various approaches such as discourse analysis, grounded theory, ethnography, semiotics and critical discourse analysis. The current research provides insight into gender-binary relations and their socially assigned roles in Pakistani context.

The present study employs semiotic analysis as a method for the critical investigation of Pakistani television commercials. Semiotic analysis unfolds the system of signification, which is based on signs. Signs are the carriers of cultural meanings promoting some underlying ideology. Dyer (1982) proposes that there is no sign in the world that is free of ideology. The method of analysis is based on the interpretative paradigm which strictly adheres to the principles drawn in the theoretical frame work.

\subsection{Data Collection}

The data for the current study comprises television commercials broadcasted on different Pakistani television channels. It includes some famous on-air television channels operating in Pakistan. The data including television commercials have been collected in phases which required keen observation of the content being aired. The researcher has properly observed some of the most viewed television channels during the prime time, that is, 7 PM to 9 PM to acquire the required data. The data collected from different television channels have been 
recorded on a DVD.

\subsection{Population}

The target Population for the present study comprises all the television channels which were on-air during the timeframe of the study.

\subsection{Sample}

The sample consists of various five broader categories which highlight the representation of gender in various spheres of human activity. In total, hundred television commercials were brought under consideration for qualitative analysis, out of which thirty commercials were excluded on account of content duplication to avoid monotony. Five commercials under each category were placed. Moreover, one commercial that is most viewed and broadcasted from each category has been considered for analysis purpose. The timeframe for the process of data collection spans over six months, that is, from July 2016 to December 2017. The sampling technique involved in the present research is based on non-probability purposive sampling.

\subsection{Theoretical Framework of the Study}

The current research employs the theory of semiotics as theoretical framework to investigate the gender representation in television commercials. Many theorists such as Williamson (1978), Dyer (1982) and Jhallay (1990) suggest that the application of semiotics is an appropriate tool for the critical inquiry of televised content which enhances the reliability and validity of the tool incorporated to investigate the questions posed in this study. The theory of semiotics is primarily based on the ideas proposed by Barthes (1977). This research banks upon the semiotic analytical model proposed by Dyer (1982), explicating the importance of denotative and connotative/ideological steps incorporated in the semiotics analysis of the commercials.

The analytical framework, this study takes into account has been proposed by Dyer (1982) to examine the textual/visual of the television commercials. The features outlined by Dyer (1982) have been adapted for the investigation of gender representational and positional value in Pakistani television commercials.

$>$ The physical description of the commercial is provided. A comprehensive visual/non-verbal analysis of commercial has been carried out keeping in view the following variables:

- $\quad$ Appearance (Age, gender, body structure and size/frequency of gender occurrence)

- Manner (Expression, eye-contact, pose and clothing)

- Activity (Body movement, physical/positional communication and props and setting)

$>$ It seeks to analyze the relevance of physical/visual description with the existing socio-cultural values. The signifiers identified at denotative level imply ideological connotations within cultural norms. The cultural underlying principles and attitudes in the media treatment of gender are explored.

This level attempts to analyze the verbal/linguistic codes employed by advertisers to dig out the hidden meanings and interpretations.

The above-mentioned Dyer's (1982) key principles which current study has adapted for the analysis of the televised content are actually based on the Barthes' (1977) essay Rhetoric of Image. The features that Barthes (1977) introduced in his essay are applicable for all kind of advertisements, television programs and films. The researcher has adapted Dyer (1982) model as it brings forth further extension of Barthes' (1977) model and it also fits in the context of the present research.

\section{Data Analysis}

This part explicates some significant methodological and theoretical steps which have been incorporated to interpret the data. It provides the interpretation of the gathered data in the light of theoretical principles drawn from the theory of semiotics. The researcher has investigated the data to answer the research questions in the light of theoretical insights.

\subsection{Section 1 (Electronic and Vehicle Commercials)}

\section{Kenwood Washing Machine Commercial}



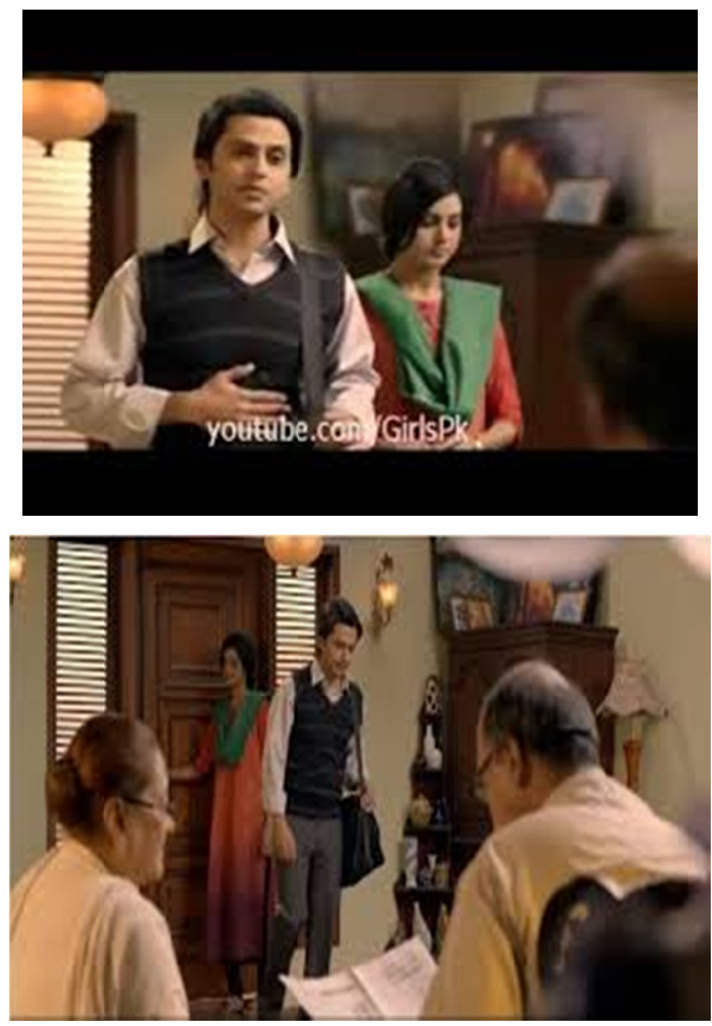

\subsubsection{Denotative Analysis}

This commercial is about a washing machine (electronic item) used to clean the clothes. The commercial starts with a young man and his wife standing in a room silently but they want to talk over some problem. A man with curly brown hair arrives there and stops them by showing a board that contains the name of the product advertised. Afterwards, the male actor is shown in an office talking to his boss. Though his boss praises the shirt and gives credit to his newly married wife but he asks him about the reason of his wearing sweater in the warm season. The young male actor answers with an excuse of his critical health and the boss is shown suggesting him to take care of his health.

The next scene is again shot in the domestic setting where the husband has been shown entering into house after spending a long day in office. The wife is presented welcoming her husband while opening the front door. The moment they enter in house, they come across parents sitting in hall. His father is shown reading a newspaper whereas the mother sitting next to him. His parents also ask him the reason of wearing sweater. The pensive expressions of his wife are quite apparent from her face. The mother is depicted worried about her son's health after she gets to know the reason of wearing the sweater. The son affirms his better health and goes upstairs to his room to get his dress changed. In his room, he takes off the sweater throwing it on the sofa and his wife seeks excuse for her mistake of burning the shirt while pressing it. He positively responds to his wife in a soft tone, asking her not to repeat as her little mistake has compelled him wear sweater all the daylong in the warm weather The wife repents for her mistake of burning the shirt but the shirt is shown clean and shining. The male actor (protagonist) is presented standing under the fan with an open shirt and wide stretched arms to enjoy the fresh air of the fan. Then, a glimpse of washing machine depicting its size and features is highlighted with a background voice praising it. The commercial ends with the name of the product, "Kenwood" and the commercial's tag line, that is, "Stay Happy".

The commercial entails five characters in all including: Nasir as a young male actor, his wife, his parent and his boss. Nasir is presented as the main actor who may range from 20 to 25 . His wife and his mother are the only female characters who are portrayed culturally dressed. His wife is dressed in decent clothes of pink color with a green scarf over it and her role suggests the simple life of a house wife. Nasir's parents are shown within domestic range where the father is portrayed reading newspaper and the mother sitting next to him. The smile on the face of his mother after seeing her son conveys a message of motherly love and satisfaction.

Dyer (1982) claims that facial/body expressions culminate meanings which are based on socially learned 
behaviors. The pensive facial expressions of wife highlighted in this commercial represent her social responsibility of properly cleaning and ironing clothes of her husband. The burnt shirt signifies her pensive expressions while the mother's smiling expression symbolizes care and purity for her son as socially learned attitude. The eye-contact among actors has been positive and directed towards audience whereas eye communication between couple reflect their understanding and love for each other.

\subsubsection{Connotative/Ideological Analysis}

Signs cultivate socially outlined constructs which help in decoding the semiotic modes employed by advertisers. Some key signifiers incorporated in this commercial are: burnt shirt, bag around male actor's arm, jewelry worn by wife and some other objects under use of the male and female actors such as newspapers in the hands of the male central actor's father, washing machine and iron. The mentioned objects are employed as signifiers which indicate the roles allotted to men/ women. They also serve to demarcate their existence in public and private spheres. Burnt shirt signifies the careless and casual attitude of wife which implies that washing and ironing husband's shirt is imperative in her responsibilities.

The other objects used as signifier in this commercial such as jewelry worn by wife and newspapers in hands of elderly male figure embody traditional identity of gender presented in Pakistani commercials. Jewelry is an ornament associated to women that makes them look more beautiful and attractive. The jewelry items worn by women in this commercial are: golden chain, golden bangles and earrings. These jewelry accessories signify the feminine beauty ideals. Vestergaard \& Shroder (1985) suggest that reason of female beauticians implies the nature of women to look more beautiful in order to grab her partner's attention. In this commercial, the feminine beauty ideals related to wife indicate her aspirations to look more attractive in order to captivate the eye of her better half which denotes the subservient and submissive attitude of women.

The binary opposition highlighted in this commercial are masculine/feminine and public/private domain. These binaries serve to identify/reproduce the representation of gender identity. The male actor in this advertisement is displayed in outdoor/public setting, performing his official tasks, while the female characters are shown confined to domestic/private range of tasks. Masculine notions can be embodied in the dictation of husband while making her realize the mistake of burning shirt and avoiding to repeat such untoward incident. The predominant image of femininity in this commercial is related to traditional role of women such as responsibility to supply the required things/objects to husband and other male members. The wives, who try to be like the ones shown in commercial actually recognize themselves as the addressee of broadcasted advertisement and position themselves submissive and inferior in gender relations. Such portrayal of the females identify their stereotypically and traditional identity

This commercial also investigates the existing modern family life, where young girls are signified independent. We are led to believe the traces of modernity in commercial but still the representation of women is stereotypically confined to traditional roles. This depiction of modern girl as a wife cannot put behind the feminine subservient notions such as serving her husband. It suggests that modern wife is still perennially a homemaker. According to Roy (1998), such portrayal of women as in this commercial not only valorizes the stereotypical and conventional role of women but it also makes it appear "natural".

\subsection{Section 2 (Food and Beverages Commercials)}

\section{K \& N Deline Food Commercial}




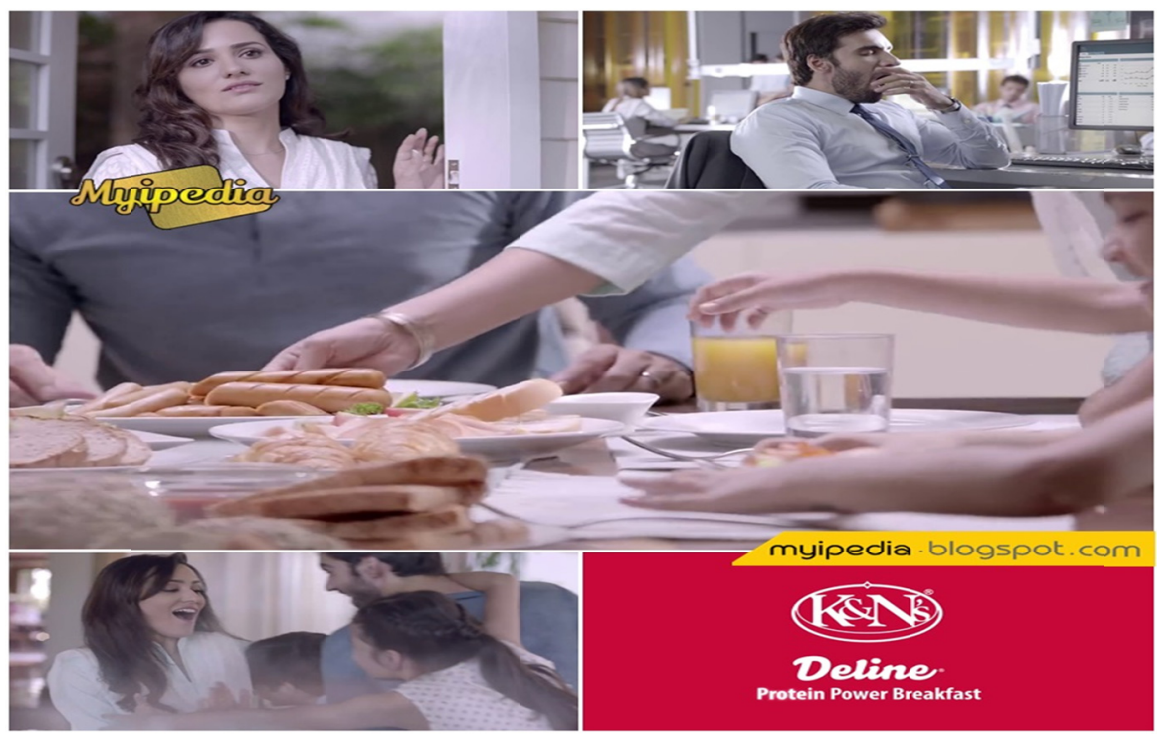

\subsubsection{Denotative Analysis}

This commercial is about a breakfast food product, K\&N Deline. The commercial revolves around a family of four; a couple, their son and daughter. The commercial begins with the scene of a mother chasing her children with a jammed slice bread while the children are playing and showing no interest in the breakfast. The daughter takes one bite of toast before her mother fetches her school bag. The husband, after getting ready for office, joins the breakfast table for a speck of seconds. He puts his black coat on the chair and his wife is displayed serving him breakfast. He takes a sip of milk and leaves the house along with children as they appear getting late. The wife escorts them till the gate, pondering over the reasons of unsatisfactory breakfast service to family. Meanwhile, her husband drives off the car. She thinks that it is impossible to do a proper breakfast in today's fast moving world. Even if they do so, the food does not serve to meet the proteins and energies required by a body for full day activity which causes exertion as well as stress. Ultimately, she curses and blames herself for not providing the quality food to family in order to uphold their physical cum mental strength.

The next scene broadcasts boys exercising in a ground. The son has been presented depressed and seated tiredly on the football with his gloved-hand attached to his cheeks. The little girl (the daughter) is also displayed sleeping and yawning in the class room and her fellows are busy in doing their class tasks. The husband yawns in the office but the rest of the employee are shown working efficiently. The following scene reflects wife working in the kitchen and seems determined to provide protein filled breakfast which could keep her family healthy and active. She enters in the kitchen again with a shopping bag in her arms, containing K\&N Deline. The next scene depicts the baking process where the rolled "Deline" is chopped into pieces and then baked. So, she has changed the breakfast ingredients and now she relies on "Deline". The product is full of protein and can be eaten in no time. The husband is shown playing and romping with his children. The commercial's exodus contains the trade mark and narration of product slogan in the voice of male, "K\&N Deline Protein Power Breakfast".

Dyer (1982) is of the view that expressions are socially learned behaviors which cultivate meanings. Expressions in commercials either display the emotive/behavioral attachment of consumers to the product advertised, or they reflect conventional schematic structures learned from societal narratives. Initially, the gloomy and sad expressions on the face of the female central character are evident of her discontentment with the breakfast served to family. The aforementioned services provided by the lady imply deep meanings which have been discussed at next level of analysis. Her facial and body expressions signify fatigue and tiring activities, to be performed on daily basis. There is less eye contact among the characters and it is more directed towards targeted audience. The activity is both indoor as well as outdoor.

\subsubsection{Connotative/Ideological Analysis}

Signs are carriers of culturally embedded meanings which are propagated through a proper system of signification (signs). Some vital signs incorporated in this commercial are: kitchen, toast/bag, jewelry accessories such as gold chain, bangles and earrings, and a vehicle (car). Kitchen is used as a signifier, connoting the premise of female central character's domain. It is synonymously linked with the socially constructed role 
assigned to woman. Apart, the female character is also frequently shown in the whole commercial, thinking to provide better hygienic and energy filled food to her family, signifying her ritual subordination as suggested by Goffmann (1979) in comparison to her male counterpart. On the other hand, jewelry accessories symbolize her feminine beauty ideals to look prettier for grabbing the eye of her better half. Toast and bag imply her responsibilities to be performed being guardian and attending the needs of her children. The vehicle shown in commercial signifies the exposure and outdoor concerns of the person who drives it. Car as well as the apparent clothing provide an insight into male central actor's domain of activity and concerns. The abovementioned signs are explained in the following paragraphs of this section.

The binary oppositions broadcasted in this commercial are: masculine/feminine and problem/solution which explicitly explicate the responsibilities, roles, positional value, activity and social standing of actors, performing various tasks. The masculine ideals highlighted in advertisement are related to driving and working in official domain. It indicates the role, responsibility and socially constructed position allocated to men. The male central character seems working that implies his economical responsibility to the family. He is presented as the sole person bearing the financial expenditure of the family, be it is related to domestic or children finances with regard to their school fee, uniforms etc. On the other hand, the son has been portrayed indulged in various activities such as studies and sports while the daughter has been either shown in classroom or in domestic premise. Their portrayal develops stereotypical understanding of gender roles/position in the minds of children since childhood. Johnson \& Young (2002) put forth the argument that advertisers in media not only focus the publicity of an item to develop the consumer culture among the targeted audience but they also develop the ideology of people by constructing gender stereotyped and conventional image in commercials. They particularly focused their study on children to investigate that how advertisements inculcate the ideology of gender structures in the minds of children. The results reveal that children are soft targeted audience who can be influenced easily as they perceive and adopt things quickly.

The dominant feminine ideal presented in commercial is double folded. The female central character has been depicted in traditional role of cooking and attending the requirements of her husband and children. Her conventional role denotes her socially defined subservient position in gender relations. On the other hand, jewelry and some other artificial ornaments worn by the female central character imply her notion of beauty ideal which make her an object of beauty/commodity. She is presented as a commodity, identifying her low status with regard to gender relations. Such representational value of woman image constructs female passive, submissive, meek and docile identity in comparison to male counterparts. The representation of men/women in this commercial seems to be in line with the findings elucidated by Vestergaard \& Shroder (1985).

\subsection{Section 3 (Medical and Personal Hygiene Commercial)}

\section{Safeguard Soap Commercial}

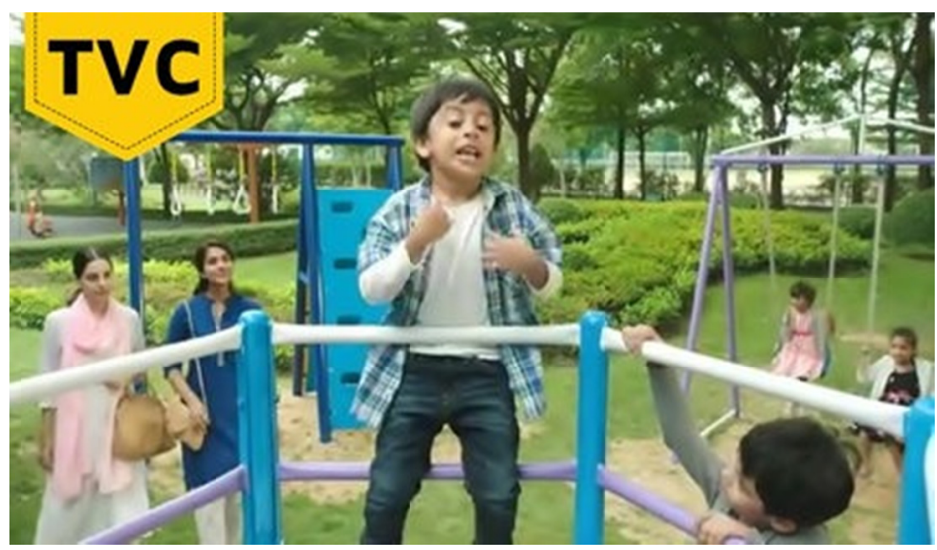

\subsubsection{Denotative Analysis}

This television commercial is about a soap, Safeguard, used for hygienic purpose to keep family away from germs. The underlined message conveys the positive aspect of product. The product protects its users from multiple non-observable germs, causing serious infections that ultimately damage health. It fights against those germs which cannot be observed through naked eye. When the advertisement starts, three kids are shown playing in park accompanied by their mothers. Boy 1 asks his friend about the reason of his mother's anxiety and he 
replies that she is worried, as she thinks that germs will make him ill. Surprisingly, he asks whether she knows the superpowers of new Safeguard. Boy 2 nods his head giving, an impression of ignorance about the powers of new Safeguard. Then, he explains to him the uses/utility of the product used for getting rid of unwanted germs. He further narrates the opinion of his mother regarding the product that it carries anti-bacterial power which fights against germs keeping us safe from disease. A male doctor has been shown, explaining the chemical formulation of the product which helps in preventing the germs. Apart from description, a visual comparative efficiency based analysis is presented where a boy is displayed, taking bath using the advertised product as well as local product. The microscopic view of germs offer better results by the use of undertaken product. Hence, the experimentation has proved that safeguard is better antibacterial soap which provides security from gems. In the end, the mother of boy 1 is shown happy while taking son in her arms and rendering her love and satisfaction. The commercial ends with the remarks of mother, explaining that safeguard is not only hers but Pakistan's best anti-bacterial soap.

The expressions of both female actors are shown in comparison indicating, their emotional attachment to two different products used for upholding hygienic standards. The eye-contact of female actors is directed at targeted audience (females) suggesting them right product to keep the family hygienically germ free. The activity has been set outdoors in a park that highlights real setting in background which naturally exists. The positional communication between the characters is "objective" and is directed to the object advertised (safeguard).

\subsubsection{Connotation/Ideological Analysis}

This commercial affirms the conventional and traditional role of Pakistani women as mothers and also highlights the role of women in the process of family socialization. It depicts conventional nature of mothers as care takers of their children and family. Vesterrgaard \& Shroder (1985) also pointed out the traditional role of women as housewives and mothers which seem to be in line to the roles assigned to women in this commercial. Mothers in this advertisement are shown attending the needs and looking for their better health prospects. It implies the stereotypical role of females in society and shows dedication and submission to family.

Signs cultivate meanings which can be deciphered within socio-cultural domain. Signs injected in this commercial are: anxiety and the brand name (Safeguard) where word safeguard has been synonymously employed and attached to the role of a mother who fights against everything which intends to damage her children or family. Words not only carry meanings but they also connote certain associations linked with them. "Safeguard", the brand name of the product is an amalgam of two separate dictionary lexemes, "Safe" and "Guard". These words can be regarded as qualifiers to describe motherly qualities. Mothers are shown curious for the well-being and upbringing of their children in the best possible manner. The commercial depicts two mothers not only thinking about their children prior to getting trapped by any disease but they have also come up with the solution of germs lest they attack. The word guard refers to "guardian" which advertisers have cleverly and traditionally attached to female characters by highlighting them curious about the health of their children. It implies that mothers are regarded as the guardian of their families who care for the betterment and wellbeing of their children and husbands. Such stereotypical portrayal of women confines their range of responsibilities within domestic domain as homemaker.

Fiske (1990b) claims that advertising, being a very persuasive source is the best way to market the products which create a sense of displacement. Here, displacement connotes interchangeable value of the product representing something else. For instance, safeguard claims that product stands at rank 1 among the other local soaps because of its anti-bacterial quality for keeping the family healthy and happy. The commercial relates the characteristics of the product advertised with that of mothers and house wives, who perform the same responsibility as safeguard does, to keep children healthy and active.

Adjectives are said to have key significance used as qualifiers for the description of product's features, size, color and number. In this commercial, the adjective is "new formula" which contains antibacterial screened germ, grabbing the attention of mothers to keep family strong and healthy. The mothers in advertisement are shown quite satisfied which reflects their emotive and behavioral attachment to the product advertised. Representing women as mothers/ wives traditionally highlights their passive status which is predominantly confined to domesticity and enforces the dominant patriarchal narrative.

The product has been promoted on two levels, indicating the first level of its usefulness (getting rid of germs) and second as a "Currency". Roy (1998) defines currency as an exchange/interchangeable value of the product. Here, the product has been promoted as an exchange value of getting love and proper upbringing of the children (mother's responsibility). On cost of the motherly love, referring to buy safeguard because of its exchange value of getting something that is intangible (love, prosperity and care). 
The insertion of male dictation portion as a medical expert in this commercial highlights the dominance of men in social relations. The male doctor has been shown dictating the benefits of the product advertised which symbolizes his positional role and authority in society. Female voiceover in background, towards the end of commercial connotes her role as a housewife, mother and her authority in household items. It also indicates her association and socially constructed role, that is, domesticity.

\subsection{Section 4 (Banking and Insurance)}

\section{Bank Alfalah Commercial}

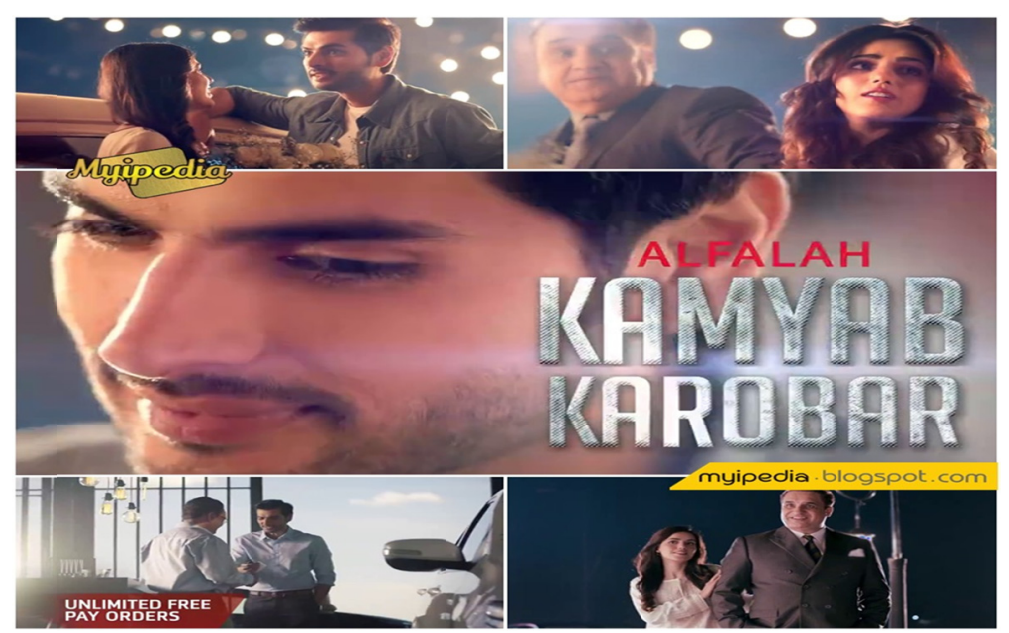

\subsubsection{Denotative Analysis}

In this commercial, Bank Alfalah is advertised as one of the leading banks which have developed several sub-branches over the period of time across the country. The commercial projects user friendly and congenial relationship between the bank and the client. Through a love story, it has been shown how this bank helps its customers in business. The commercial begins with a background male voice which tells that a boy Kamran and a girl Ayesha want to marry. Kamran is giving present/gift to Ayesha while standing near his old fashioned early 20th century car. In the meanwhile, her father comes in a modern car and reprimands Kamran for having a wish to marry his daughter. This shows that Kamran is from lower class and the girl is from higher class. Instead of cursing his poverty, writing lyrics, being closed in a room and sending messages of sorrow, Kamran opens an account in Bank Alfalah, writes cheques, sends transaction and spreads his business with the help of the bank.

In this way, he becomes a very successful businessman and has been shown in his own car showroom. Now, he has more expensive vehicles than the girl's father and can be ranked as a member of higher social stature. In the end, the girl's father comes and smiles giving a positive gesture that he is willing to marry off his daughter with him. Ayesha comes to Kamran when he spreads his arms for her. The message in this commercial is that Bank Alfalah helps in becoming a successful businessman and with a successful business you can get the things you desire.

The commercial consists of three central actors including Kamran (the male actor), Ayesha (the female actor) and her father (the male actor). Apart from these three main characters, some other male characters have also been depicted working and performing diverse tasks in the background of commercial. Kamran and Ayesha are portrayed young, energetic and ambitious who intend to get embedded in a wed-lock. Apparently, both appear a perfect match but difference in their background with regard to social class, has become hurdle for them which prevents them from doing so. Dyer (1982) posits that emphasis of the advertisers is always on the young actors/actresses whose age ranges from 18-35 because mostly the advertised products address youth. The hair style and clothes worn by both male and female central actors give an idea of modernity. The open long hair of the girl project her an object of beauty. Initially in commercials, the looks of the girl's father signify power, authority and superiority over other characters.

The expressions of Kamran (the male central actor) denote dejection and frustration after getting rejected as a suitable match for the one whom he loved most. His association with Bank Alfallah brought a positive hope for him to excel in his own business. This association has developed a sense of competition which took him forward 
in his professional grooming and development. Advertisers have implicitly generated an underlying ideology by showing the success accomplishment of the protagonist in this commercial. Facial and physical expressions of the protagonist approve the reliability and validity of banking services, advertised in this commercial. In advertising, there is almost no denotative communication. Although it is useful to distinguish between denotation and connotation for analytical purposes, denotation is not neutral or untouched by ideology. It may seem to be more fixed and taken for granted but it is still dependent upon a context of meaning and association. The supposed absence of a code at the iconic, denotative level merely reinforces the myth of photographic naturalness. According to Barthes (1977), "It innocents the semantic artifice of connotation, which is extremely dense in advertising (p. 45)".

\subsubsection{Connotative/Ideological Analysis}

This section sets out to investigate the symbolic and connotational value of signs and semiotic modes delineating ideological narratives. Signs are the basic units of a commercial which help reader understand the implied meanings within a cultural context because the meanings conveyed by signifiers vary from culture to culture. This televised content contains bouquet, posters of brand new vehicles on wall, sliding doors of a garage, papers shown in air, cheque book and rising sun as key signifiers. Each sign attached to actor's role and performance connote meaningful interpretation.

Moreover, the white flowers in bouquet are representative of not only purity and innocence but they also symbolize honesty and perfection in relationships. Presenting white roses in a relation also signifies the element of honor and respect that is being bestowed in the recognition of beginning of new life. It denotes to pay homage and gives hope for the future life. This commercial also begins with the depiction of intimate relationship between Kamran and Ayesha where Kamran presents her a bouquet of white roses expressing sincere, pure and honest feeling towards her. Their dream of starting a new life together got shattered by a dominant patriarchal structure in the shape of Ayesha's father. The role assigned to Ayesha's father in this commercial is the representation of existing strong patriarchal narrative in Pakistani society. Father has been shown compelling his daughter not to get married with a person who is socially inferior to them. He forcefully takes his daughter away with him which projects the submissive attitude of women in Pakistani context. Men (Father) have been portrayed powerful, authoritative and assertive.

The image of sliding gate wide opened by young actor, cheque book and the rising sun connote the exploration of a new world by utilizing his energies in the right direction. In the context of this commercial, it also promotes an underlying ideology in the context of this commercial that men are less emotional and sentimental in comparison to their counterparts. The voice of male in the background of commercial narrates the hard efforts rendered by the young actor in spite of idly sitting like a lover and doing nothing. His determination and will took him forward to his desired destination. Consequently, Ayesha's father had to believe in the abilities of young Kamran who brought himself up to their social status. Class consciousness is also one of the subsidiary themes employed by advertisers. The dominant image of masculinity represented in this commercial is that male of field operation aspiring for success and glory.

The entire commercial comprises the male voice-over in the background narrating the story of success. The study conducted by Das (2010) postulated that ratio of male characters acting as voice-overs dominated the female characters in Indian television commercials. Female voice over are only seen in commercial dealing with domestic product publicity whereas men voice over are generally found in all types of commercials. The voice-over in this commercial seems in line with the previously discussed study.

\subsection{Section 5 (Cleansers and Detergents)}

\section{Bonus Tristar Commercial}




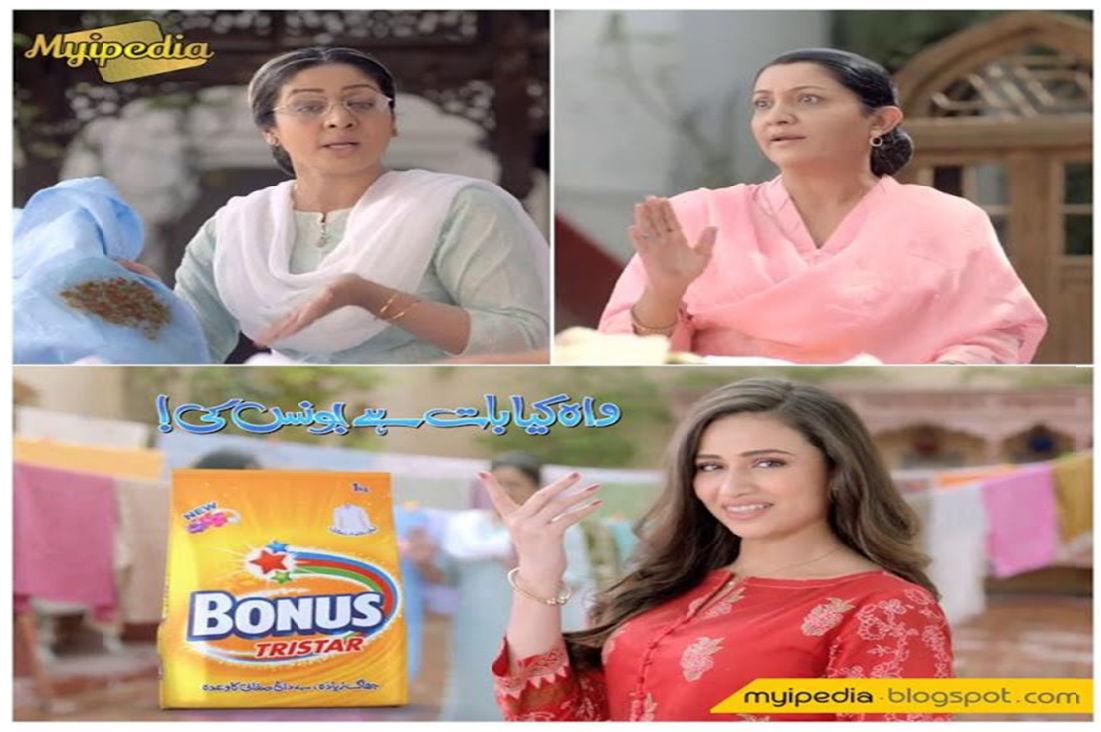

\subsubsection{Denotative Analysis}

The first step of analysis emphasizes the physical description and literal meanings which advertisers have incorporated in the form of visual imagery. Main signifiers employed in the commercials are also identified and what they connote have also been discussed in later half of the analysis. This commercial is about a washing powder, named Bonus Tristar. It starts with mother-in-law sitting and talking to her guest friend. They are talking about the difficulties of their passed youth age and criticizing the present age of the daughter-in-law or daughter-in-law herself in other words. They mention that it was difficult to crush the edible things because they used to crush them in mortar with pestle but now the young girls run grinding machines. They also talk about the way of washing cloths and cleaning the hard strains of curry and mud by rubbing for a long time but the young girls use washing powder. Here, the daughter-in-law says that it is not an ordinary washing powder rather it is Bonus Tristar. Both the women are surprised by listening that it is new Bonus and then they come to the clothes washed by that powder. When they see the shine of clothes and inhale the sweet fragrance of the powder, they are really impressed and mother-in-law's friend admits the fact that this is her age. In subcontinent, the disputes between mother-in-law and daughter-in-law are quite common issues. In the advertisement, it has been shown that this issue can be solved by using Bonus washing powder. That is why the daughter-in-law gives credit to Bonus in the end. The symbol of three star shows that the powder brings stars like shine in clothes and the flowers flying from the clothes show that it gives the clothes a very sweet natural and flowers like fragrance.

This commercial is void of male characters which suggests that domestic associated activities are not of men's domain. Three female characters shown in the commercial, represent two different time frames projecting their traditional norms which might have varied over the passage of time. Mother-in-law and her friend are representative of shared cultural values prevalent 30 years ago whereas the daughter-in-law is representative of the present values shared by modern 21 st century people. A comparative technique has been employed by advertiser to unfold the development in domestic material used for washing purpose in general but implicitly it promotes an underlying ideology regarding the gender roles. Age is a crucial factor which carries implied meanings. Here, characters having age above 40 and below 25 are equally represented. The physical movement of the characters is restricted to indoor setting. Body structure of actors seems to be quite positive.

\subsubsection{Connotative/ Ideological Analysis}

The signifiers in this commercial are very technically juxtaposed which connote deeper meanings. The activity performed by the actor/actress defines his/her role in the commercial. The moment commercial begins, we have seen a quite young and attractive girl indulged in an activity of washing clothes. The signifiers such as washing machine, juicer machine and dirt filled shirt are attached with the domain of a young girl's activity. The role given to young girl in this commercial identifies the prevalent gender narrative. Why has a girl been shown performing the task of washing the clothes? The existing cultural norms define the responsibilities of gender assignments and tasks. The advertising agencies tend to reinforce and endorse the socially defined gender narrative. 
The Cultivation theory propounded by Gerbner \& Gross (1976) posits that commercials and advertisements frame the ideological behavior, approach and attitude of masses. Commercials, representing women in the limited domains of activity, are stereotyping their roles and tasks. Butler (1990) defines gender as it is something that we "do" or "perform" instead of being born with biologically different. Society draws a line of demarcation between the men and women by assigning them different roles. This commercial is self-evident that all female actors have been taken as brand ambassador of the product that is being used for washing. And actresses' frame of physical activity has also been limited and domesticized. Moreover, Holmstorm (2004) further explains that People are likely to believe what they watch and at the same time ideology depicted in the image, proves to be social reality for them.

The product "Bonus Tristar" is a product that has been produced by the dominant patriarchy and is based on the consumerist ideology of women exploitation. As the commercial's description suggests that women accept the ideology claimed by the product advertiser and the experience of the same make it a reality. Women as an audience, considering themselves the addressee of the commercial are actually practicing the hegemonic patriarchal ideology. By showing women happy and pleased while enjoying their authority in domestic affairs not only asserts the confined traditional role of women but also naturalizes and conventionalizes it.

Several other semiotic modes incorporated in the commercial such as colors, flowers with sweet fragrance and bright white shirt also provide deeper ideological message. Some signifiers have got conventionalized meaning and they add symbolic value whenever they are associated with any product. For instance, flowers have been shown thrice in this commercial which connote double meanings. Flowers are symbolically epitome of freshness and fragrance. Therefore, the qualities of flowers have been interchanged and merged into the product (Bonus Tristar). Flowers can be identified as a metaphor in this commercial. The symbol of three stars reflects purity, completeness and self -fulfillment. White brightened shirt is also used as a symbol which may be interpreted as transformation of advertiser's claim into reality. The brightness and fragrance is the outcome of the product used for washing purpose. The dressing and clothing of the young girl signifies a tinge of modernity but still she has been shown upholding feministic ideals of domestication.

\subsection{Section 6 (Cellular Companies/Mobile Network)}

\section{Jazz Network Commercial}

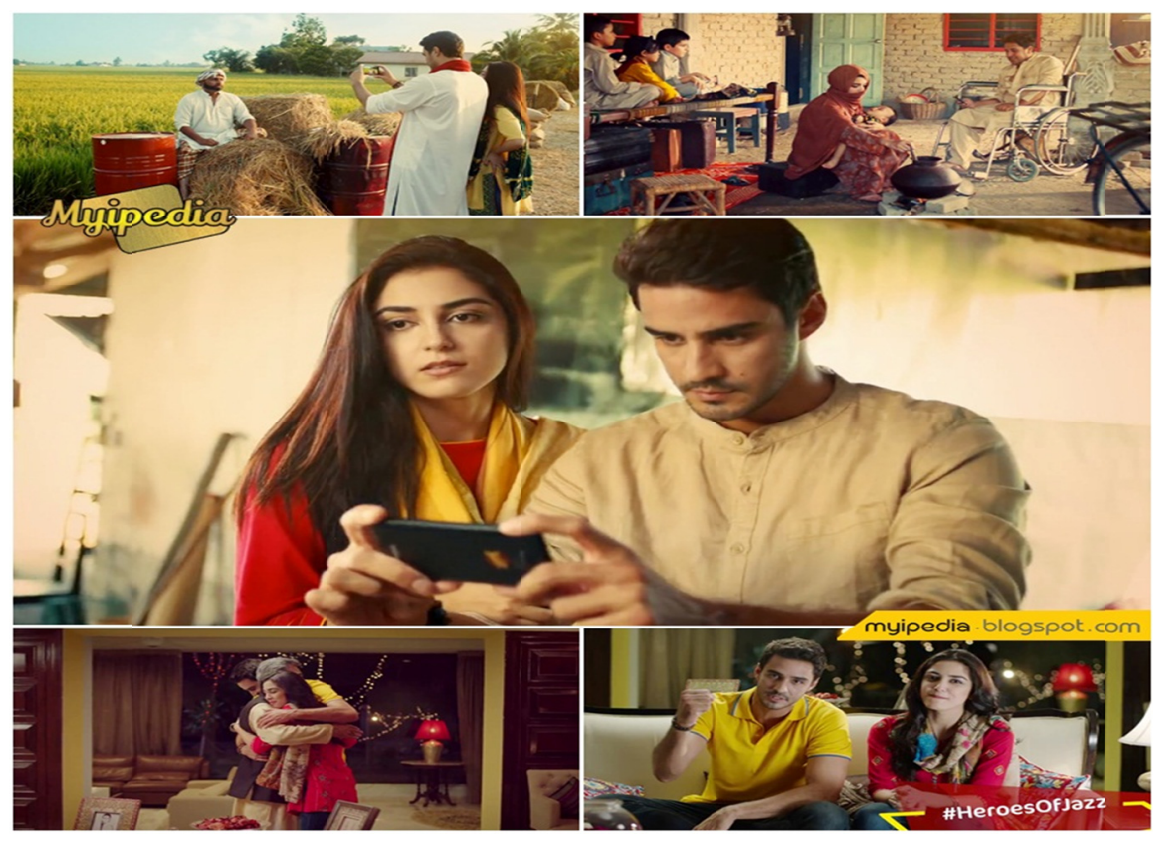

\subsubsection{Denotative Analysis}

The focus of this commercial is to inculcate awareness and patriotic feelings among the Pakistani nationals settled abroad through internet services provided by Mobilink Jazz. Mobilink Jazz is shown one of leading and most facilitative mobile networks functioning in the most backward and rural areas across Pakistan. This 
television commercial involves both literal and oral narratives but the major part of it consists of visual and spoken codes. The consumer's attention is captured by stirring up their emotive associations with native land. The concept of patriotism is the foundational pillar of this advertisement. The commercial begins with a girl sitting in the premises of some abroad university, talking to a foreign student. The foreigner asks her where is she from and the girl replies that she is from Pakistan. The expressions of foreign student displayed after knowing her national identity imply a negative stereotyped image of Pakistan due to which Pakistani girl got offended. The brother of that Pakistani girl is shown quite nearby who has also overheard their conversation. Moreover, the girl discusses the matter with her brother blaming Pakistani media for negative reporting and projecting the image of their country which has ultimately developed a negative terrorist stereotyped narrative across the world.

However, they decided to alter this undesirable ideology of terrorism associated with Pakistan among the foreign nationals. They planned to go back Pakistan and help improve the image of their nation in the world. They had to face criticism and their father does not seem happily agreed with their decision. The technique implemented by these actors was to visit far-flung rural and backward areas capturing the hard work and miserable life of people. In order to promote these captured videos on social media, they required a good network connection to show the ground realities and for this they chose Mobilink Jazz.

This advertisement, later on, shots success stories of some rural families where facility of Jazz internet has brought revolution in the fields such as farming. For instance, a farmer is shown happy because his son has saved crops from getting destroyed due to frequently obtained tips gained from several e-farming generated sources on websites. Another story shown is that of a young literate girl living in some remote area where she is not permitted to step out and wants to educate others. She brings the school to her home by uploading her videos for the school children. In the end, a person living abroad with his family, finally decides to come back Pakistan after watching success stories being shared by these actors which got viral over the passage of time. Finally, the siblings succeed in their mission of upbringing their nation's name in the world and their father is proud of them now. Emotional appeal is quite dominant throughout this advertisement and is the source of persuasion for the consumers.

This commercial entails numerous actors categorizing them into central/major and supporting characters. The central actors in commercial are both brother and sister who launched a campaign to uplift and truly represent their identity as a nation across the world. Some minor actors have also been introduced in rural setting whose reflection also signify the gender narrative. The age of all actors taken in this commercial, ranges from 20 to 40 and representation of men/ women is proportioned according to roles assigned to them. Initially, the foreign national characters are also portrayed who have stereotyped image of Pakistan which sets the agenda of this commercial. Body structure, clothing, physical movement and overall looks of actors give an impression of existing social demarcation of people on the basis of color, caste, wealth and education.

\subsubsection{Connotative/Ideological Analysis}

The girl shown abroad for the purpose of higher education gives an impression of subverting ritual subordination and confined role of women. Her apparent looks with regard to her dress, hair, positional communication and expression suggest modernized style of life. The paradigm of her activity is not restricted to domesticity rather it appears broad, elevating the worth of country by truly projecting identity of people as a nation. Such positive representation of women is rarely found in advertisements as it challenges the hegemony of patriarchal ideology. Deckard (1985) goes on to say that women can effectively work in a pluralistic environment and can bring productive social change. In this commercial, girl shown working and studying in a pluralistic environment is determined to bring a change in the projection parameters which earn a bad name for their country. Her dedication and hard work over the course of time has shown positive results. The visual aspect of clothing carries meanings which can be explained in a specific cultural context. The dress worn by girl during her stay at abroad is seemingly different from that of her dress worn in Pakistan which connotes that existing cultural values in Pakistan do not permit her wear that dress.

In addition, the representation of other supportive characters displayed performing activities in diverse contexts also offer underlying connotations which provide a holistic overview of existing Pakistani cultural norms. In rural setting, the portrayal of interviewed farmer and his villagers highlights the type of activity and role assigned to those people. Several props are employed which have got culturally conventionalized meanings such as sickle. Sickle is an instrument which functions to cut the crops. A farmer has been shown in open fields working and looking after the harvest indicating that men are stereotypically attached/associated with outdoor activities. Men are considered to be physically stronger than their counterparts. Contrary to public portrayal of men in outdoor activities, a lady in miserable condition has been shown performing indoor activity of cooking 
and having children in her lap. She has also veiled her face with Dupata (a cloth used for covering head in Pakistani context) signifying the prevalent norms. The dual role assigned to female in this commercial identifies the confined stereotyped role of women within the range of domesticity.

In the end, a literate girl is shown imparting education to children of her town. The background voice-over explains that she is not allowed to step out of her domestic range defining the weird norms of that vicinity. In this commercial while depicting backward rural setting, the culturally imposed weird bindings regarding women outdoor activities have been brought to limelight. On the other hand, the girl has also been displayed involved in teaching activity which is thought to be quite suitable profession for ladies, again developing a stereotyped narrative with regard to their representation. According to Global Media Monitoring Project (2010) report, there has been a huge difference of the ratio in representation of men and women.

This commercial can be classified as a combination of complex and sophisticated type of advertisements because of its unusual startup. The first scene of the commercial has been shown set in a foreign country arousing the emotive sense of the actors. Such advertisements explore the relationship between the product advertised and environment in which commercial has taken place. It intends to arouse subconscious feelings of characters by putting in circumstances where it gets difficult to understand as to what has actually been advertised. Same technique has been implemented in commercial by arousing the patriotic feelings of characters in the beginning of commercial.

\section{Conclusion}

The commercials taken as sample for the investigation of gender representational value in the Pakistani context do not seem challenging to conventional power narrative where men and women are stereotypically portrayed. This leads to draw a concluding remark that the Pakistani electronic televised content (commercials) subscribes to existing imbalanced/stereotypical gender structures where men/women are traditionally presented while performing their conventional/stereotyped roles within their socially allocated domains. Advertising, being a persuasive source makes such portrayal appear natural, thereby, promoting the patriarchal ideological narrative. The media representation of gender not only develops the ideology of audience as a persuasive medium but it also compels us to perceive the way it presents gender roles, position and level of authority. The images of masculine and feminine voices displayed in the commercials strengthen our ideological beliefs about what we think as masculine or feminine.

\section{References}

Barthes, R. (1977). Rhetoric of the image. London: Collins Sons and Co.

Bretl, D. J., \& Cantor, J. (1988). The portrayal of men and women in U.S. television commercials: A recent content analysis and trends over 15 years. Sex Roles, 18(9-10), 595-609. https://doi.org/10.1007/BF00287963

Cook, T. E. (2005). Governing with the news: The news media as a political institution. Chicago: University of Chicago Press. https://doi.org/10.7208/chicago/9780226026688.001.0001

Courtney, A. E., \& Whipple, T. W. (1983). Sex Stereotyping in Advertising. Heath, 14(3), 67-67. Lexington, MA: D. C.

Craig, R. S. (1992). The effect of television day part on gender portrayals in television commercials: A content analysis. Sex Roles, 26(5-6), 197-211. https://doi.org/10.1007/BF00289707

Craig, S. (1992). Men, Masculinity, and the Media (pp. 1-7). London: Sage. https://doi.org/10.4135/9781483326023

Das, M. (2010). Gender Role Portrayals in Indian Television Ads. Sex Roles, 64(3-4), 208-222. https://doi.org/10.1007/s11199-010-9750-1

Deckard, G. J. (1985). Work stress, mood, and ecological dysfunction in health and social service settings.

Dyer, G. (1982). Advertising as communication. London: Methuen. https://doi.org/10.4324/9780203328132

Fiske, J. (1990). Introduction to communication studies. London: Routledge.

Gerbner, G., \& Gross, L. (1976). Living with Television: The Violence Profile. Journal of Communication, 26(2), 172-194. https://doi.org/10.1111/j.1460-2466.1976.tb01397.x

Goffman, E. (1979). Gender Advertisements. New York: Macmillan Books.

Jhally, S. (1990). The codes of advertising: Fetishism and the political economy of meaning in the consumer 
society. New York: Routledge.

Johnson, F., \& Young, K. (2002). Gendered voices in children's television advertising. Critical Studies in Media Communication, 19(4), 461-480. https://doi.org/10.1080/07393180216572

Lemish, D. (2005). Exclusion and Marginality: Portrayals of Women in Israeli Media. Women and Media, 39-59.

McNair, B. (2003). An introduction to political communication. London: Routledge.

Polkinghorne, D. (1983). Methodology for the human sciences: Systems of inquiry. Albany: State University of New York Press.

Roy, A. (1998). Images of Domesticity and Motherhood in Indian Television Commercials: A Critical Study. The Journal of Popular Culture, 32(3), 117-134. https://doi.org/10.1111/j.0022-3840.1998.3203_117.x

Sutherland, M. B., Gilbert, P., \& Taylor, S. (1992). Fashioning the Feminine: Girls, Popular Culture and Schooling. British Journal of Educational Studies, 40(3), 309. https://doi.org/10.2307/3120908

Vestergaard, T., \& Shroder, K. (1985). The Language of Advertising. New York: Blackwell.

Williamson, J. (1978). Decoding advertisements: Ideology and meaning in advertising. London: Boyars.

\section{Copyrights}

Copyright for this article is retained by the author(s), with first publication rights granted to the journal.

This is an open-access article distributed under the terms and conditions of the Creative Commons Attribution license (http://creativecommons.org/licenses/by/4.0/). 